FACTA UNIVERSITATIS

Series: Physical Education and Sport, Vol. 16, No 3, 2018, pp. 631 - 640

https://doi.org/10.22190/FUPES181009057Y

Research article

\title{
INTERVAL VERSUS CONTINUOUS SMALL-SIDED SOCCER GAMES WITH SAME PITCH SIZE AND NUMBER OF PLAYERS
}

\author{
UDC 796.015.57 \\ 796.332:612
}

\section{Mehmet Yücesoy ${ }^{1}$, Nurtekin Erkmen ${ }^{1}$, Samet Aktas ${ }^{1}$, Faruk Güven ${ }^{2}$, Mehmet Durmaz ${ }^{1}$}

${ }^{1}$ Faculty of Sport Sciences, Selçuk University, Konya, Turkey

${ }^{2}$ School of Physical Education and Sport, Kilis 7 Aralık University, Kilis, Turkey

\begin{abstract}
The aim of the study is to compare the effects of intermittent and continuous small-sided games (SSGs) on physiological and technical activities in soccer players. In total 16 male amateur soccer players (Mean age: $22.37 \pm 1.69$ years, height: $170.89 \pm 5.96 \mathrm{~cm}$ and body mass: $67.37 \pm 7.47 \mathrm{~kg}$ ) were recruited as participants. The participants were separated into 4 groups of 4 players according to the Yo-Yo test results and their coaches' comments. Four-a-side SSGs were used in a pitch size of 26 $m \times 34 m$ and 2 different small-sided games were used in this study. Intermittent SSG (ISSG) included a series of 3 bouts of 6 min duration with 3 min recovery between sets. Continuous SSG (CSSG) was a bout of 18 min duration with no recovery. Heart rate $(H R)$, the rating of perceived exertion (RPE), and blood lactate concentration (LA) were measured as physical parameters, while shot on target, total pass, accurate pass, inaccurate pass, interception, dribbling, tackle, and possession of the ball were counted by Mathball Match Analyses System. A repeated measures ANOVA method, paired and unpaired tests, was used to analyze the data. The results of this study suggest that SSGs might cause increases of HR, RPE, and LA and that intermittent.
\end{abstract}

Key words: Match analyses, small-sided games, soccer, technical actions, physiological responses

Received October 9, 2018 / Accepted December 28, 2018

Corresponding author: Samet Aktas

Faculty of Sport Sciences, Selçuk University, Konya, İstanbul Cad. 369, 42130 Selçuklu-Konya, Turkey

Phone: +332 $2410041 \cdot$ E-mail: sametaktas@ selcuk.edu.tr 


\section{INTRODUCTION}

The power of the lower extremities, strength, speed and endurance in a soccer game are the components of performance for a soccer player (Nikolaïdis, 2012). 11\% of the total distance covered during a game consists of short distance sprints with change of direction that provides more possession of the ball (Hazır, Mahir, \& Açıkada, 2010). Because soccer has many and complicated movements during a match, there are many factors affecting performance. The leading factors that affect performance in soccer are the technical skills and the capacity of endurance (Helgerud, Engen, Wisløff, \& Hoff, 2001). Due to the fact that the game duration in soccer is long, players tackle in larger fields and the running time related to continuous attack and defense during the entire game is longer; soccer trainings are deemed important in terms of speed, agility and some anthropometric features (Başer, 1996).

On the other hand, taking into consideration the duration of a soccer competition, soccer is seen as heavily predicated on the aerobic energy system. While 80 to $90 \%$ of the game duration consists of low to moderate intensity actions, 10 to $20 \%$ of the game duration involves high intensity actions (Bangsbo, 1994). The work load is close to the anaerobic threshold in any soccer competition and is thereabouts 80 to $90 \%$ of the maximal heart rate. The blood lactate levels that rise during the effort make it impossible to maintain the high intensity exercise throughout the competition (Střlen, Chamari, Castagna, \& Wislřff, 2005). The heart rate during a soccer competition is above 150 beats per minute (bpm) and the level of blood lactate could reach up to $12 \mathrm{mmol} / \mathrm{L}$. On the other hand, the average blood lactate level is about $7 \mathrm{mmol} / \mathrm{L}$ (Ekblom, 1986). It was noted that competitions are played at a heart rate that corresponds to $70 \%$ of $\mathrm{VO}_{2}$ max and the levels of lactate differ from 3 to $9 \mathrm{mmol} / \mathrm{L}$ (Bangsbo, 1994).

The games played for the purpose of preparation for soccer competitions in training, which are played in smaller fields, with fewer players and for shorter durations have different names as small sided games (SSGs), tactical games, condition purposed games and endurance games (Impellizzeri et al., 2006). The SSGs often take place in training sessions because they allow physical, technical and tactical practices at the same time besides reflecting the conditions of competition realistically (MacLaren, Davids, Isokawa, Mellor, \& Reilly, 1988). Additionally, the SSGs provide productive and efficient training in a short span of time through advancing players' skills and improving players' decision making abilities (Aguiar et al., 2012). Due to this fact, SSGs are used widely and in a multidimensional manner to develop players' talents in a way that variable purpose-oriented rules can be applied (Drust, Reilly, \& Cable, 2000; Gabbett, 2002; Reilly \& Gilbourne, 2003; Sassi, Reilly, \& Impellizzeri, 2003).

Another important issue in soccer is the match analysis, which is defined as the evaluation of actions that each individual player exhibits or a team as a whole, with or without a ball, and as examination of these actions' success levels. The actions of a player during a soccer competition may vary depending on many conditions such as competition conditions, capacities and goals of the players. Match analysis is based on observing all factors such as the game pitch, forms of kicks and passes, duration and players. After, it is developed with deductions made from team behavior that is classified according to the observed actions (Gören, 2011). Because coaches consider the notations obtained from soccer match observations valuable data, much software for match analysis is developed to ensure data during competitions for soccer, basketball, handball, etc. In the beginning, coaches or their assistants used hand taking notes with the help of some special codes to record players' actions. However, as the significance of these evaluations has been 
understood over time, these manual inputs have not been considered sufficient enough and the necessity of a recording system has arisen. The systems that allow recordings of the players' actions thanks to the help of computers were designed in the 1980's (Eniseler, Antrenman1, \& Matbaacilık, 2010). Match analysis software also helps us to observe the actions in the SSGs used in soccer practices as well as actions in soccer games. On the other hand, soccer requires interval forms of actions rather a form continuous during a competition (Impellizzeri et al., 2006). Results of studies show that SSGs improve aerobic capacity (Impellizzeri et al., 2006; Hill-Haas, Rowsell, Dawson, \& Coutts, 2009). However, a limited number of studies have focused on comparing actions in interval SSG and continuous SSG (Hill-Haas et al., 2009; Fanchini et al., 2011; Köklü, 2012). Hill-Hass et al. (2008) and Fanchini et al. (2011) stated that continuous SSG were played with a higher percentage of maximum heart rate than intermittent SSG. Köklü (2012) suggests that intermittent and continuous SSGs could improve the aerobic capacity of soccer players. The responses to these SSGs among soccer players needs to be understood.

Therefore, we investigated whether there was any difference between effects of the continuous SSGs and the intermittent SSGs on the physiological parameters and technical actions in soccer players.

\section{METHODS}

A total of 16 male amateur soccer players (Mean age; 22.37 \pm 1.69 year, height; $170.89 \pm 5.96 \mathrm{~cm}$ and body mass; $67.37 \pm 7.47 \mathrm{~kg}$ ) volunteered for the study as participants. The participants had no serious injury in the last 6 months. All players were tested during the competition period. To detect the $\mathrm{VO}_{2} \max$ levels of the participants, a Yo-Yo intermittent recovery test (YYIRT) was conducted before the study, and the participants were separated into 4 groups with 4 players according to both the YYIRT and opinions of the team coach. The study was conducted in official size soccer fields with artificial turf following international standards.

The soccer practices should aim at the technical, tactical and physiological development in a multidirectional manner. Because coaches often give place to small sided games in practice, sport scientists focused on the examinations of these games' effectiveness (Aguiar, Botelho, Lago, Maças, \& Sampaio, 2012). Therefore, a wide range of studies that investigate the effects of components such as field sizes, number of players, application of rules on the technical-tactical and physiological responses have been conducted (Mallo \& Navarro 2008; Castagna, Impellizzeri, Cecchini, Rampinini, \& Alvarez, 2009; Castellano et al., 2016; Katis \& Kellis, 2009; Kelly \& Drust 2009).

\section{Small-Sided Games (SSGs)}

A $26 \mathrm{~m}$ wide and $34 \mathrm{~m}$ length game pitch was used for the small sided games in the study. The small sided games were practiced in two ways: intermittent small sided game (ISSGs) and continuous small sided games (CSSGs). The ISSGs was played in periods of 6 min, interspersed with 3 min of passive recovery. The CSSGs included an $18 \mathrm{~min}$ period of games without any rest period. A goalkeeper did not take position and the offside rule was not applied in both of the small sided games. The field sizes and game durations used in the small sided games were determined using previous studies (Torres-Ronda et al., 2015; 
Rampinini et al., 2007; Brandes, Heitmann, \& Müller, 2012; Aguiar et al., 2012; Castellano et al., 2013). The SSGs were practiced with a minimum of 3-day intervals.

\section{Measures}

Monitoring Heart Rate: Heart rates (HR) of the soccer players before, during and after the small sided games were evaluated and recorded by a heart rate monitor (Polar RS810; Polar-Electro, Kempele, Finland) which is able to record at intervals of 5 seconds.

The Rating of Perceived Exertion (RPE): 15 points Borg scale (Borg 1970) was used for determining the RPE during small sided games.

Blood Lactate Level: Blood lactate levels of the soccer players were measured by a portable lactate analyzer (Lactate Scout, Sens Lab, Leipzig, Germany) before the beginning of SSGS, after each set and after the end of SSGs.

HRs, RPEs, and blood lactate measurements in ISSGs were taking 4 times: 1 time before ISSGs, at the end of each 3 sets. The same variables in CSSGs were measured 2 times: Before and after the CSSGs.

\section{Analysis of the SSGs}

The SSGs were recorded through a digital camera (Nikon D3300 Body DSLR, Nikon Corporation, Japan) placed on top of a fixed tripod which was located 5 meters above and 10 meters away from the game field. The digital images obtained via camera records were evaluated by using computerized notational analysis techniques by the Mathball (Algoritma Bilgi Islem LLC), a computer assisted match analysis program. The technical actions performed during the SSGs were qualified as 8 different variables. These actions were the shot (goal attempt), the total passes, the accurate passes, the inaccurate passes, the interception, the dribbling, the tackle, and ball possession. The technical actions during the ISSGs were evaluated separately for each set and a total of 3 sets was taken into consideration.

\section{Statistical analysis}

Data were expressed as mean \pm standard deviations (SD). The Shapiro-Wilks test was used as a test of normality. A Repeated Measures ANOVA was used to compare variables with normal distribution. The t-tests were conducted for both the paired and unpaired comparisons. The Mann Whitney $\mathrm{U}$ and Wilcoxon tests were conducted to compare variables without normal distribution. The significance level was set at .05. SPSS (Statistical Package for the Social Sciences) 22.0 program was used for the data analysis.

\section{RESULTS}

Table 1 Descriptive statistics of the participants (Mean \pm SD)

\begin{tabular}{lrr}
\hline Variables & \multicolumn{1}{c}{ ISSG } & \multicolumn{1}{c}{ CSSG } \\
\hline Age $($ year $)$ & $22.29 \pm 1.68$ & $22.46 \pm 1.76$ \\
Height $(\mathrm{cm})$ & $171.29 \pm 5.99$ & $170.46 \pm 6.15$ \\
Weight $(\mathrm{kg})$ & $67.16 \pm 6.67$ & $67.58 \pm 8.47$ \\
VO2Max $(\mathrm{ml} / \mathrm{kg} / \mathrm{min})$ & $52.84 \pm 4.31$ & $53.60 \pm 3.35$ \\
Max. HR $(\mathrm{bpm})$ & $191.64 \pm 6.22$ & $196.22 \pm 6.50$ \\
\hline
\end{tabular}

ISSG: intermittent small sided game, CSSG: Continuous small sided game 
Table 2 The mean values of HRs, RPEs and lactate levels before and after the SSGs

\begin{tabular}{llcc}
\hline Variables & & Pre-Test & Post-Test \\
\hline HR $(\mathrm{bpm})$ & ISSG & $105.00 \pm 11.97$ & $179.94 \pm 6.04 \dagger$ \\
& CSSG & $93.13 \pm 10.80^{*}$ & $176.63 \pm 12.41 \dagger$ \\
\hline \%HRmax & ISSG & $55.72 \pm 8.18$ & $94.10 \pm 4.91$ \\
& CSSG & $48.98 \pm 5.99$ & $90.82 \pm 8.83$ \\
\hline RPE & ISSG & $7.38 \pm 0.72$ & $13.79 \pm 0.73$ \\
& CSSG & $7.00 \pm 0.00^{*}$ & $13.63 \pm 1.15$ \\
Blood Lactate (mmol/lt) & ISSG & $2.37 \pm 0.64$ & $11.30 \pm 1.68$ \\
& CSSG & $2.36 \pm 0.72$ & $9.76 \pm 2.82$ \\
\hline
\end{tabular}

* Significantly different from ISSG $(\mathrm{p}<0.05) ; \uparrow$ Significantly different from pre-test $(\mathrm{p}<0.05)$

The results of the variance analysis for repeated measures showed that the small sided games caused a significant change in $\operatorname{HR}\left(\mathrm{F}_{(1.30)}=1278.790 ; \mathrm{p}<0.05\right)$. While the interaction of Group x Small Sided Game did not cause a significant change in $\operatorname{HR}\left(\mathrm{F}_{(1.30)}=3.735 ; \mathrm{p}>\right.$ $0,05)$, the SSGs caused a significant change in the HR variable $\left(\mathrm{F}_{(1.30)}=8389.165 ; \mathrm{p}<0.05\right)$. According to paired comparisons, the HRs of the ISSG group was significantly higher than the HRs of the CSSG group before the games $(t=2.946 ; \mathrm{p}=0.006)$. There was no significant difference between groups after the games $(t=0.960 ; p=0.345)$. HRs significantly increased after the ISSG $(t=-30.392 ; \mathrm{p}<0.000)$. Similarly, HRs significantly increased after 18 minutes CSSG $(t=-22.684 ; \mathrm{p}<0.000)$. Similar to the results of the HR in the study, the results of the repeated measures ANOVA showed that SSGs significantly affected the \%HRmax $\left(\mathrm{F}_{(1.18)}=1235,317 ; \mathrm{p}<0,05\right)$. The interaction of factor $\mathrm{x}$ group was not significant for the \%HRmax $\left(\mathrm{F}_{(1.18)}=29.721 ; \mathrm{p}>0.05\right)$. Also, The SSGs caused no significant difference in the \%HRmax $\left(\left(\mathrm{F}_{(1.18)}=2.813 ; \mathrm{p}>0.05\right)\right.$. According to the paired comparisons, there was no significant different between SSGs in the pre-test $(\mathrm{t}=2.058 ; \mathrm{p}>$ $0.05)$ and post-test $(\mathrm{t}=1.051 ; \mathrm{p}>0.05)$. After the SSGs, \%HRmax increased as expected in both CSSG $(\mathrm{t}=-24.008 ; \mathrm{p}<0.05)$ and ISSG $(\mathrm{t}=-26.240 ; \mathrm{p}<0.05)$.

According to analyzed results, there was a statistically significant difference between RPE scores before the SSGs $(\mathrm{U}=96.000 ; \mathrm{p}=0.036)$. The RPE scores of SSGs were similar after the games $(\mathrm{U}=97.000 ; \mathrm{p}=0.224)$. When comparing pre- and post-test scores, RPE scores were significantly higher on the post-test than the pre-test $(Z=-3.525$; $\mathrm{p}=0.000$ for ISSG, $\mathrm{Z}=-3.654 ; \mathrm{p}=0.000$ for $\mathrm{CSSG}$ ).

Table 3 The technical actions in the ISSG and the CSSG

\begin{tabular}{lrrr}
\hline Variables & \multicolumn{2}{c}{ ISSG } & \multicolumn{2}{c}{ CSSG } \\
\hline Shot & $1.25 \pm 0.46$ & $3.00 \pm$ & $1.85^{*}$ \\
Total Pass & $50.75 \pm 13.53$ & $40.88 \pm$ & 8.69 \\
Accurate Pass & $35.63 \pm 9.16$ & $28.50 \pm$ & $\pm .17^{*}$ \\
Inaccurate Pass & $15.13 \pm 5.79$ & $16.13 \pm 3.64$ \\
Dribbling & $5.38 \pm 4.14$ & $2.00 \pm 2.00^{*}$ \\
Interception & $7.00 \pm 3.16$ & $4.63 \pm 4.03^{*}$ \\
Tackle & $1.25 \pm 1.28$ & $0.63 \pm 1.06$ \\
Ball possession (sec) & $120.75 \pm 33.93$ & $141.38 \pm 67.69$ \\
\hline \multicolumn{2}{c}{$*$ Significantly different from the ISSG $(\mathrm{p}<0.05)}$.
\end{tabular}

* Significantly different from the ISSG $(\mathrm{p}<0.05)$. 
According to the results of the repeated measures ANOVA, SSGs affected the blood lactate levels significantly $\left(\mathrm{F}_{(1.30)}=379.935 ; \mathrm{P}=0.05\right)$, the interaction of factor $\mathrm{x}$ group was not significant $\left(\mathrm{F}_{(1.30)}=3.385 ; \mathrm{p}>0.05\right)$; however, there was no significant difference between the groups $\left(\mathrm{F}_{(1.30)}=3.192 ; \mathrm{p}<0.084\right)$. When comparing pre- and post-test scores, blood lactates were significantly higher on the post-test than the pre-test $(\mathrm{t}=-21.426 ; \mathrm{p}<0.000$ for ISSG, $\mathrm{t}=$ $-10.177 ; \mathrm{p}=0.000$ for CSSG).

According to results of a comparisons between the games; the number of shots in the CSSG was significantly higher than that of the ISSG $(\mathrm{U}=56.000 ; \mathrm{p}=0.004)$. Total pass was not significantly different between the SSGs $(U=80.000 ; p=0.069)$. On the other hand, the accurate pass in the ISSG was significantly higher than in the CSSG (U = $68.000 ; \mathrm{p}=0.023)$. There was no significant difference between the SSGs in the inaccurate pass $(\mathrm{U}=108.000 ; \mathrm{p}=0.447)$. Dribbling and interception in the ISSG were significantly higher than the CSSG $(U=62.000 ; p=0.011$ and $U=70.000 ; p=0.027$, respectively). There was no significant difference between the SGSs in the tackles (U = 80.000; $\mathrm{p}=0.052)$ and the possession times $(\mathrm{U}=84.000 ; \mathrm{p}=0.097)$.

\section{DISCUSSION}

The results of the study pointed out that both of the small sided games caused a significant rise in HR. It can be said that the post-game HR results were similar for both types of small sided games, in other words, there was no significant difference in HRs between the post-ISSG and post-CSSG.

In a study carried out by Aktaş, Erkmen, Guven, \& Taskin (2014), the recovery times between the sets of SSGs were applied as $3 \mathrm{~min}$ and $5 \mathrm{~min}$. It was stated that there were significant differences in HRs between the first and second sets of the SSGs that include 3 min and 5 min break times. Yet the HRs after the third sets were similar to each other. In a study carried out by Fancini et al. (2011); the SSGs were applied as 3 sets of 2, 4 and 6 min with 4 min recovery times for each, when there were 3 players per team. The authors stated a similarity for the HR responses in these SSGs.

Considering the fact that heart rates during a soccer match are between 160-170 bpm (Bangsbo, 1994) and the mean value of the heart rates was $178.28 \pm 9.75 \mathrm{bpm}$ in the recent study, it can be said that HRs in the SSGs are higher than in a soccer competition. Dellal et al. (2008) noted a similar HR response between some small sided game formats and short time intermittent running trainings. Due to this fact, small sided games can be effective for training aerobic capacity.

According to the results of the study, the rating of perceived exertion (RPE) of the soccer players was $7.18 \pm 0.54$ before the small sided games, and it reached up to $13.71 \pm$ 0.95 after the games. A study revealed the effects of varied recovery times on RPE, and noted that there was no difference in RPEs between the SSGs included 3 min or 5 min recovery times (Aktaş et al., 2014). Fanchini et al. (2011) applied the SSGs as 3 sets consisting of 2, 4 and 6 min and gave 4 min recovery times between each pair of sets. The authors indicated an absence of difference in RPE levels between the SSGs.

The mean RPE was 12.2 after the 24 min continuous small sided game applied as 4 vs. 4 (Hill-Haas et al., 2008). In another study, 4 vs. 4 small sided games were applied as 4 sets consisting of 4 min each. The mean RPE was stated as 10.98 after that small sided game where the size of the game field was $47.5 \mathrm{~m}$ x $28.5 \mathrm{~m}$ (Hazır \& Açıkada, 2016). 
Köklü (2012) investigated the physiological responses of young soccer players within the intermittent and continuous small sided games that varied in the number of players and in pitch size. Köklü stated that 3 vs 3 and 4 vs. 4 intermittent and 3 vs. 3 continuous small sided games can be used in training for developing maximal oxygen uptake.

When the blood lactate responses of soccer players after small sided games are analyzed, a significant increase in blood lactate levels can be seen after both of the small sided games. The inference that small sided games cause a marked accumulation of blood lactate can be made according to this result. On the other hand, it is thought that the blood lactate responses after ISSG and CSSG do not differ from each other, blood lactate responses of the intermittent and continuous small sided games were similar in the way that this study was conducted.

The ability to develop lactate tolerance through 2 vs. 2 continuous and intermittent SSGs and the ability to develop an anaerobic threshold through 4 vs. 4 SSGs games could be improved (Köklü, 2012). In a study of 3 vs. 3 SSGs which were applied as 3 sets consisting of 6 min each, with variable recovery times, the blood lactate levels significantly increased after the games. Considering the recovery times, the blood lactate levels in the SSGs including $3 \mathrm{~min}$ recovery duration were higher than the levels in the games including $5 \mathrm{~min}$ recovery times (Aktaş et al., 2014).

Köklü's study (2012) included 2 vs. 2, 3 vs. 3 and 4 vs. 4 SSGs that were applied as 3 sets with $2 \mathrm{~min}, 4 \mathrm{~min}$ and $6 \mathrm{~min}$ bout durations within the variably sized game fields. The author stated that the blood lactate levels were $7.8 \mathrm{mmol} . \mathrm{L}^{-1}, 6.8 \mathrm{mmol} . \mathrm{L}^{-1}$ and $6.7 \mathrm{mmol} . \mathrm{L}^{-1}$, respectively.

Considering the technical actions performed in the SSGs, it can be seen that the number of goal attempts during the CSSG was higher than the one in ISSG. The numbers of accurate passes, dribbling and interception during the ISSG, on the other hand, were higher than the ones during the CSG. There were no differences in the number of total passes, inaccurate passes, tackles and ball possession times between the ISSG and the CSSG; in other words applying the SSGs as intermittent or continuous had no impact on the numbers of passes, inaccurate passes, tackles and ball possession times.

Güven, Erkmen, Aktas, \& Taskin (2016) conducted an SSG including 3 sets consisting of $6 \mathrm{~min}$ with $5 \mathrm{~min}$ recovery duration throughout a study held in two game fields which differed in size $(20 \mathrm{~m} \times 34 \mathrm{~m}$ and $30 \mathrm{~m} \times 40 \mathrm{~m})$. After the study investigated the possible influences of a game field's size, it is stated that the numbers of the goal attempts, winnings of the ball, accurate passes, misplaced passes, dribbling and possession time was not influenced by the size of the game pitch, so technical actions done in two different small sided games were similar to each other.

Fanchini et al. (2011) investigated the possible influences of different small sided game durations on the exercise density and the technical actions. A game field with a size of $31 \mathrm{~m}$ x $37 \mathrm{~m}$ was used, and 3 vs. 3 small sided game that included 3 sets with 4 min break times were used in the study. Although a small sided game was applied with 2 min, 4 min and 6 min loads, it is stated that no differences in the technical actions between the small sided games were found.

Hill-Haas et al. (2009) compared the acute physiological responses and time-motion characteristics respecting the ISSG ( 4 × 6 min bouts with $1.5 \mathrm{~min}$ passive rest) and the CSSG (24 min with no rest). They did not find any difference in LA between the ISSG and the CSSG although authors reported RPE and \%HRmax were higher in the CSSG 
than in the ISSG. They concluded that both intermittent and continuous regimes of SSG could be performed to expose soccer players to competition conditions.

\section{CONCLUSION}

The HR, RPE and BL significantly increased after the ISSG and CSSG that was played on a $26 \mathrm{~m}$ x $34 \mathrm{~m}$ size game field and that included 18 min game duration in total for each game. However, there were no differences in the HR, \%HRmax, RPE and blood lactate between the 18 min CSSG and ISSG which included sets consisted of 6 min each, in other words, both types of games gave similar responses in terms of the HR, \%HRmax, RPE and blood lactate. Some alterations were observed in certain technical actions between the continuous and intermittent SSGs, while the number of goal attempts were significantly higher in the CSSG; the number of accurate passes, dribbling and interception were significantly higher in the ISSG. The number of passes, inaccurate passes, tackles and ball possession times were similar in both kinds of SSGs. The study used a 3 min recovery duration between sets of the ISSG. In future studies, longer recovery duration could be selected, or pitch size in the SSG could be enlarged.

\section{REFERENCES}

Aguiar, M., Botelho, G., Lago, C., Maças, V., \& Sampaio, J. (2012). A review on the effects of soccer smallsided games. Journal of Human Kinetics, 33, 103-113.

Aktaş, S., Erkmen, N., Guven, F., \& Taskin, H. (2014). Effects of the different recovery durations on some physiological parameters during 3 x 3 small-sided games in soccer. International Science Index, 8(12, Part I), 134-139.

Bangsbo, J. (1994). Fitness training in football. Denmark: August Krogh Institute, University of Copenhagen.

Baser, E. (1996). Futbolda psikoloji ve başari, sporsal kuram dizisi (Psychology and success in football, a series of sports theories). 4 (2). Baski, Ankara. In Turkish

Borg, G. (1970). Perceived exertion as an indicator of somatic stress. Scandinavian Journal of Rehabilitation Medicine, 2, 92-98.

Brandes, M., Heitmann, A., \& Müller, L. (2012). Physical responses of different small-sided game formats in elite youth soccer players. The Journal of Strength \& Conditioning Research, 26(5), 1353-1360.

Castagna, C., Impellizzeri, F., Cecchini, E., Rampinini, E., \& Alvarez, J.C.B. (2009). Effects of intermittentendurance fitness on match performance in young male soccer players. The Journal of Strength \& Conditioning Research, 23(7), 1954-1959.

Castellano, J., Silva, P., Usabiaga, O., \& Barreira, D. (2016). The influence of scoring targets and outer-floaters on attacking and defending team dispersion, shape and creation of space during small-sided soccer games. Journal of Human Kinetics, 51(1), 153-163.

Castellano, J., Casamichana, D., \& Dellal, A. (2013). Influence of game format and number of players on heart rate responses and physical demands in small-sided soccer games. The Journal of Strength \& Conditioning Research, 27(5), 1295-1303.

Dellal, A., Chamari, K., Pintus, A., Girard, O., Cotte, T., \& Keller, D. (2008). Heart rate responses during small-sided games and short intermittent running training in elite soccer players: a comparative study. The Journal of Strength \& Conditioning Research, 22(5), 1449-1457.

Drust, B., Reilly, T., \& Cable, N.T. (2000). Physiological responses to laboratory-based soccer-specific intermittent and continuous exercise. Journal of Sports Sciences, 18(11), 885-892.

Ekblom, B. (1986). Applied physiology of soccer. Sports Medicine, 3(1), 50-60.

Eniseler, N., Antrenmanı, B.I.F., \& Matbaacılık, B. (2010). Bilimin işı̆̆ında futbol antrenmanı (Football training in the light of science). Manisa. In Turkish. 
Fanchini, M., Azzalin, A., Castagna, C., Schena, F., Mccall, A., \& Impellizzeri, F. M. (2011). Effect of bout duration on exercise intensity and technical performance of small-sided games in soccer. The Journal of Strength \& Conditioning Research, 25(2), 453-458.

Gabbett, T. J. (2002). Training injuries in rugby league: an evaluation of skill-based conditioning games. Journal of Strength and Conditioning Research, 16(2), 236-241.

Gören, H. (2011). Müsabaka ve taktik analiz (Competition and tactical analysis). Fourth Training Science Congress, (pp. 28-30). Haziran, Ankara. In Turkish

Guven, F., Erkmen, N., Aktas, S., \& Taskin, C. (2016). Small-sided games in football: Effect of field sizes on technical parameters. Sport Scientific \& Practical Aspects, 13(2), 35-43.

Hazır, S., \& Açıkada, C. (2016). Physiological and kinematic responses to small sided games in soccer: Comparison with the training match. Hacettepe Journal of Sport Sciences, 27(4), 193-210.

Hazır, T., Mahir, Ö. F., \& Açıkada, C. (2010). Relationship between agility and body composition, anaerobic power in young soccer players. Hacettepe Journal of Sport Sciences, 21(4), 146-153.

Helgerud, J., Engen, L.C., Wisløff, U., \& Hoff, J. (2001). Aerobic endurance training improves soccer performance. Medicine \& Science in Sports \& Exercise, 33(11), 1925-1931.

Hill-Haas, S., Coutts, A., Rowsell, G., \& Dawson, B. (2008). Variability of acute physiological responses and performance profiles of youth soccer players in small-sided games. Journal of Science and Medicine in Sport, 11(5), 487-490.

Hill-Haas, S.V., Rowsell, G.J., Dawson, B.T., \& Coutts, A.J. (2009). Acute physiological responses and timemotion characteristics of two small-sided training regimes in youth soccer players. The Journal of Strength \& Conditioning Research, 23(1), 111-115.

Impellizzeri, F.M., Marcora, S.M., Castagna, C., Reilly, T., Sassi, A., Iaia, F. M., et al. (2006). Physiological and performance effects of generic versus specific aerobic training in soccer players. International Journal of Sports Medicine, 27(06), 483-492.

Katis, A., \& Kellis, E. (2009). Effects of small-sided games on physical conditioning and performance in young soccer players. Journal of Sports Science \& Medicine, 8(3), 374.

Kelly, D.M., \& Drust, B. (2009). The effect of pitch dimensions on heart rate responses and technical demands of small-sided soccer games in elite players. Journal of Science and Medicine in Sport, 12(4), 475-479.

Köklü Y.A. (2012). Comparison of physiological responses to various intermittent and continuous small-sided games in young soccer players. Journal of Human Kinetics, 31, 89-96.

MacLaren, D., Davids, K., Isokawa, M., Mellor, S., \& Reilly, T. (1988). Physiological strain in 4-a-side soccer. In T. Reilly, A. Lees, \& K. Davids (Eds.), Science and Football. London, E\&FN Spon.

Mallo, J., \& Navarro, E. (2008). Physical load imposed on soccer players during small-sided training games. Journal of Sports Medicine and Physical Fitness, 48(2), 166-171.

Nikolaïdis, P. (2012). Development of isometric muscular strength in adolescent soccer players. Facta Universitatis Series Physical Education and Sport, 10(3), 231-242.

Rampinini, E., Impellizzeri, F. M., Castagna, C., Abt, G., Chamari, K., Sassi, A., \& Marcora, S. M. (2007). Factors influencing physiological responses to small-sided soccer games. Journal of Sports Sciences, 25(6), 659-666.

Reilly, T., \& Gilbourne, D. (2003). Science and football: a review of applied research in the football codes. Journal of Sports Sciences, 21(9), 693-705.

Sassi, R., Reilly, T., \& Impellizzeri, F. (2003). A comparison of small-sided games and interval training in elite Professional soccer players. Communication to the Fifth World Congress of Science and Footbol, Lisbon, 2003, (pp. 11-15).

Střlen, T., Chamari, K., Castagna, C., \& Wislřff, U. (2005). Physiology of soccer: an update. Sports Med, 35, 501-536.

Torres-Ronda, L., Gonçalves, B., Marcelino, R., Torrents, C., Vicente, E., \& Sampaio, J. (2015). Heart rate, time-motion, and body impacts when changing the number of teammates and opponents in soccer smallsided games. The Journal of Strength \& Conditioning Research, 29(10), 2723-2730. 


\section{INTERVALNE NASPRAM KONTINUIRANIH IGARA NA UMANJENIM TERENIMA ISTIH DIMENZIJA I BROJA IGRAČA}

Cilj ove studije je da se uporede efekti intervalnih $i$ kontinuiranih igara na umanjenim terenima (SSGs), na fiziološke i tehničke sposobnosti fudbalera. U istraživanju je učestvovalo 16 fudbalera amatera (prosečna starost: $22.37 \pm 1.69$ godina, visina: $170.89 \pm 5.96 \mathrm{~cm}$ i telesna masa: $67.37 \pm 7.47$ $\mathrm{kg}$ ). Na osnovu rezultata Yo-Yo testa i sugestija trenera, ispitanici su podeljeni u 4 grupe. Na terenu dimenzija 26 m x $34 \mathrm{~m}$, korišćen je Four-a-side SSGs, kao i još dve igre. Intervalni program je uključivao tri serije igre u trajanju od po 6 minuta, sa tri minuta pauze između serija. Kontinuirani trening na umanjenim dimenzijama terena je uključivao 18 minuta igre bez prekida. Za procenu fiziološkog statusa utvrđeni su srčana frekvenca (HR), nivo zamora (RPE), kao i koncentracija laktata u krvi (LA), dok je za procenu tehnike korišćen šut u metu, ukupan broj dodavanja, preciznog dodavanja, nepreciznog dodavanja, presretanja lopte, driblinga, obaranja igrača i poseda lopte, pri čemu su svi podaci obrađeni pomoću sistema za obradu podataka (Mathball Match Analyses System). Za utvrđivanje razlika korišćen je ANOVA metod za ponovljena merenja. Rezultati studije sugerišu da primena igara na smanjenim dimenzijama terena dovodi do porasta vrednosti srčane frekvence, nivoa zamora i nivoa laktata u krvi.

Ključne reči: analiza meča, igre na umanjenim terenima, fudbal, tehnika, fiziološki odgovor 